\title{
Prevalence of Theileria equi and Babesia caballi Infections in Horses in South Gujarat, India
}

Suresh V. Mavadiya, Ramesh M. Patel ${ }^{1}$, Sudhir A. Mehta, Arshi A. Vagh², Irshad H. Kalyani, Jayesh B. Solanki, Nikhil S. Dangar, Dharmesh R. Patel

10.18805/IJAR.B-4392

\begin{abstract}
Background: Equine piroplasmosis (EP) is a tick-borne disease of horses caused by the intraerytrocytic protozoan parasites. The infected animals remain carriers of these blood parasites for long periods and spread the disease. The introduction of carrier animals into areas where competent tick vectors are prevalent can lead to an epizootic spread of the disease.

Methods: Total 295 blood smears from diseased and healthy horses were examined and 295 serum samples were analyses by cELISA for the presence of antibodies against $T$. equi and B. caballi whereas 90 DNA samples from seropositive horses were screened by PCR for presence of parasite's DNA.

Result: In present study, $1.35 \%$ horses were found positive for $T$. equi by means of blood smear examination. Using C-ELISA, it was found that $03(1.02 \%)$ horses had antibodies against $B$. caballi and $182(61.69 \%)$ against $T$. equi, while none of the sample showed mixed reactions. Ninety (90) seropositivehorses screened for $T$. equi and B. caballi by PCR method, out of which, only Nine (09) horses werefound positive indicating an overall prevalence rate of $T$. equi was $10.00 \%$ by PCR. None ofthe horses found positive for B. caballi through blood smear examination and PCR method.
\end{abstract}

Key words: Babesia caballi, cELISA, Horse, PCR, Theileria equi.

\section{INTRODUCTION}

Equine piroplasmosis (EP) is a tick-borne disease caused by Babesia caballi and Theileria equi that affects horses, mules, donkeys and zebras. Both parasites are transmitted by ticks of genera Dermacentor, Rhipicehalus and Hyalomma. The disease is reported from many parts of India (Sanjeev et al. 2020). In 2004, the OIE approved the competitive Enzyme Linked Immunosorbent Assay (cELISA) for detection of antibodies against $T$. equi and $B$. caballi and as a specified test for global horse activity (OIE, 2014)

The prevalence rates of the $T$. equi were earlier reported by many workers in Gujarat and adjoining states using blood smear examinations and PCR (Sumbria et al. 2016, Vidhyalakshmi et al. 2018; Bharai et al. 2020; Sanjeev et al. 2020). However, a different level of sero-prevalence of antibodies against $T$. equi was documented from various states of India (Khurana et al. 2014; Dahiya et al. 2018; Bhojani et al. 2021). There is no previous serological study focusing on the occurrence of $T$. equi infection in horses of south Gujarat in India, therefore,-present study was conducted to determine the prevalence of $T$. equi and $B$. caballi in horses by blood smears and to identify the presence of $T$. equi antibodies in the serum of horses with cELISA.

\section{MATERIALS AND METHODS}

\section{Sample collection}

The present study was conducted from March, 2016 to March, 2020. Blood samples from horses were collected using vacutainer tubes with or without anticoagulant. The samples were transported under refrigeration to the
Department of Veterinary Medicine, Veterinary College, Navsari Agricultural University, Navsari-396 450, Gujarat, India.

${ }^{1}$ Department of Veterinary Clinics, Veterinary College, Sardarkrushinagar Agricultural University, Dantiwada-385 506, Gujarat, India.

${ }^{2}$ Department of Veterinary Medicine, Veterinary College, Junagadh Agricultural University, Junagadh-362 001, Gujarat, India.

Corresponding Author: Suresh V. Mavadiya, Department of Veterinary Medicine, Veterinary College, Navsari Agricultural University, Navsari-396 450, Gujarat, India.

Email: dr_svmavadiya@yahoo.co.in

How to cite this article: Mavadiya, S.V., Patel, R.M., Mehta, S.A., Vagh, A.A., Kalyani, I.H., Solanki, J.B., Dangar, N.S. and Patel, D.R. (2021). Prevalence of Theileria equi and Babesia caballi Infections in Horses in South Gujarat, India. Indian Journal of Animal Research. DOI: 10.18805/IJAR.B-4392.

Submitted: 30-12-2020 Accepted: 01-04-2021 Online: 29-04-2021

laboratory and blood smear were prepared. Samples were finally stored at $-20^{\circ} \mathrm{C}$ for molecular analysis.

\section{Serological detection of $T$. equi and $B$. caballi by cELISA}

The blood was collected from jugular vein of horses into a serum clot activators. The blood samples were centrifuged at $3000-3500 \mathrm{rpm}$ for $15-30$ minutes. The serum was separated and stored at $-20^{\circ} \mathrm{C}$ until performing cELISA. The stored serum samples were assessed for the presence of antibodies to $T$. equi and $B$. caballi using a commercial cELISA test kit (VMRD, Inc., Pullman, USA) following the manufacturer's instructions. The optical density (OD) of the controls and samples were measured at $630 \mathrm{~nm}$ wave length 
Table 1: Reaction components for VetPCR ${ }^{\mathrm{TM}}$ as per VMRD kit.

\begin{tabular}{|c|c|c|c|c|}
\hline Kit components & Samples & Positive control & Negative control & Internal contro \\
\hline T. equil B. caballi Premixture & $5.5 \mu \mathrm{L}$ & $5.5 \mu \mathrm{L}$ & $5.5 \mu \mathrm{L}$ & \\
\hline PCR Internal control & & & & $5.5 \mu \mathrm{L}$ \\
\hline DNase/RNase free water & $6 \mu l$ & $6 \mu l$ & $6 \mu l$ & $6 \mu l$ \\
\hline DNA isolated from the sample & $2 \mu l$ & & & $2 \mu l$ \\
\hline T. equi / B. caballi PCR Positive control & & $2 \mu l$ & & \\
\hline PCR Negative control & & & $2 \mu l$ & \\
\hline Mineral Oil Solution & $11 \mu \mathrm{l}$ & $11 \mu \mathrm{l}$ & $11 \mu \mathrm{l}$ & $11 \mu l$ \\
\hline
\end{tabular}

using an automatic microplate reader (Cyberlab, R01, USA) and the percentage of inhibition (\%) was calculated as follows:

I $(\%)=100-($ sample OD $\times 100) /($ mean OD of three negative controls)

Serum samples with $\geq 40 \%$ inhibition were considered positive and samples with $<40 \%$ inhibition were considered negative as per the manufacturer guidelines.

\section{Molecular detection of T. equi by PCR}

Total 90 blood samples were selected randomly from the horses showed seropositivity. The DNA was extracted from blood samples as per the protocol outlined in the user manual. VetPCR ${ }^{\text {TM }}$ detection Kit (VMRD, Inc., Pullman, USA) was used to detect the DNA of $T$. equi and $B$. caballi.

The products obtained were subjected to electrophoresis (100 volts, 45 minutes) in agarose gels at $2 \%$ in TBE with GelRed. Samples that showed amplificationproducts with a size of $499 \mathrm{bp}$ ( $T$. equi) were considered as positive (Fig 1). Reaction mixture was prepared for sample, positive control, negative control and internal control by combining the reagents as shown in Table 1 and PCR cycling protocol in Table 2.

\section{Statistical analysis}

The data were subjected to statistical analysis using chisquare test and R-software version 3.6.3 as per the method described by Snedecor and Cochran (1994).

\section{RESULTS AND DISCUSSION Microscopic examination of blood smears}

Blood smears were shown to have a low sensitivity (1.35\%) to detect Babesia and Theileria parasites, although it is a simple, inexpensive and useful tool to diagnose the disease in the field. Identification of equine piroplasmosis in carrier animals by means of blood smear examination is difficult, inaccurate and not practical, on large-scale; serological methods are preferred (OIE, 2014). Prevalence studies conducted in other areas of India reported different levels of positivity as $4.17 \%$ from Punjab (Deepak et al. 2016), $5.05 \%$ from Gujarat (Vidhyalakshmi et al. 2018), 5.71\% from Republic of Guinea and India (Diallo et al. 2018), 6.97\% from Mathura, U.P. (Sanjeev et al. 2020), 63.41\% from Junagadh, Gujarat (Bharai et al. 2020) and only one horse found positive out of 151 blood smears for $T$. equi using blood smear examination (Bhojani et al. 2021).
Table 2: PCR protocol followed for Theileria equi DNA amplification.

\begin{tabular}{lcr}
\hline Steps & Temperature and Time & Cycle \\
\hline Initial denaturation & $94^{\circ} \mathrm{C}$ for 2 minutes & 1 cycle \\
Denaturation & $94^{\circ} \mathrm{C}$ for 30 Second & 30 cycles \\
Annealing & $55^{\circ} \mathrm{C}$ for 30 Second & \\
Extension & $72^{\circ} \mathrm{C}$ for 30 Second & \\
Final extension & $72^{\circ} \mathrm{C}$ for 5 minutes & 1 cycle \\
\hline
\end{tabular}

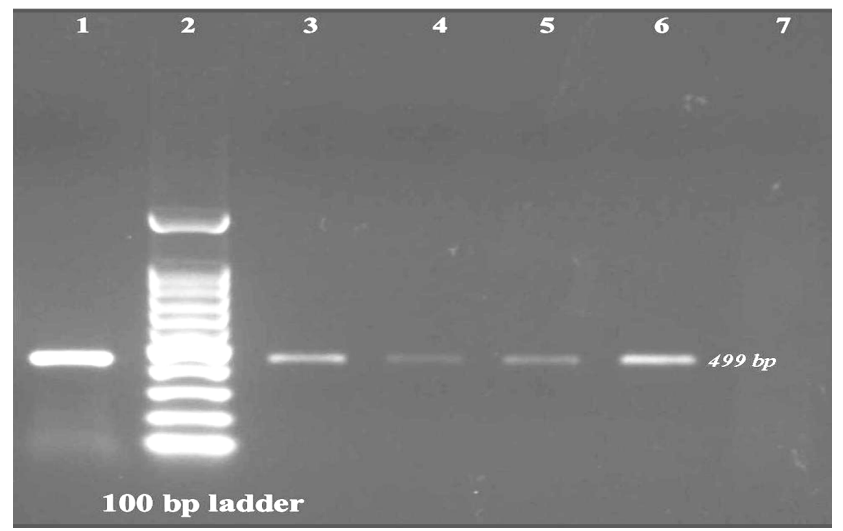

Fig 1: Agarose gel electrophoresis showing amplified DNA of Theileria equi (499bp).

Lane-1: Positive control, Lane-2: DNA ladder, Lane-3 to 6: Tested field samples and Lane-7: Negative control.

\section{cELISA for detection of $T$. equi and $B$. caballi}

In the present research, the overall prevalence of equine piroplasmosis was $62.71 \%(185 / 295)$ by cELISA, out of which $61.69 \%(182 / 295)$ for T. equi and $1.02 \%(03 / 295)$ for B. caballi (Table 3$)$. Similarly, very law $0.55 \%(01 / 182)$ prevalence of $B$. caballi was reported using cELISA in Gujarat by Vidhyalakshmi (2015) whereas Khurana et al. (2014) carried out sero-surveillance of T. equi on 291 samples collected from various states of India and overall prevalence of $T$. equi was $24.66 \%$. Bhojani et al. (2021) carried out a cross-sectional study on the seroprevalence of $T$. equi using cELISA in 151 horses from Bikaner, Rajasthan state, out of which 75/151 (49.66\%) were found positive for $T$. equi. The high prevalence of piroplasmosis might be due to the carrier animals responsible for the maintenance of the infection. Warm humid environment favours the tick vectors and high incidence of disease (Patel et al. 2013). The highest positive sample for T. equiby cELISA 
Prevalence of Theileria equi and Babesia caballi Infections in Horses in South Gujarat, India

Table 3: Prevalence rate of $T$. equi and $B$. caballi in horses.

\begin{tabular}{lcccc}
\hline Species & Blood smears $(\mathrm{N}=295)$ & cELISA(N=295) & PCR(N=90) & $P$ value \\
\hline Theileria equi & $04(1.35 \%)$ & $182(61.69 \%)$ & $09(10.00 \%)$ & 00 \\
Babesia caballi & 00 & $03(1.02 \%)$ & 0.00001 \\
Overall & $04(1.35 \%)$ & $185(62.71 \%)$ & $09(10.00 \%)$ & $<0.00001$ \\
\hline
\end{tabular}

in the present study could be due to presence of antibodies of particular parasites in animal's body. These findings are suggestive and supportive that animals might have come in contact with the parasite and developed antibodies approximately ten days after post-infection. Antibodies against $B$. caballi usually last about four years and in the case of $T$. equi, developed antibodies remain for life as reported by De Waal (2004).

\section{PCR for detection of T. equi and B. caballi}

Out of 90 seropositive horses screened for $T$. equi by PCR, 9 horses were found positive indicating an overall prevalence rate of $10.00 \%$ by PCR while none of the samples showed the presence of DNA for B. caballi. (Table 3). It was in agreement with that of Vidhyalakshmi et al. (2018) who reported $11.52 \%$ horses positive for $T$. equi from Gujarat State by PCR method. In contrarily to our study, 33.33\% prevalence of Theileria species in equines had been reported by Deepak et al. 2016 from Punjab state. Whereas, $48.14 \%$ for $B$. caballi and $29.63 \%$ prevalence rates for $T$. equi were reported from Saurashtra region of Gujarat by Bharai (2018). Comparable findings were accounted in area of Mathura (Uttar Pradesh) and boarder areas of Rajasthan by Sanjeev et al. (2020) who recorded $10.46 \%$ prevalence rate of $T$. equi by PCR. Similarly, Diallo et al. (2018) carried out molecular analysis of $T$. equi from various agro-climatic zones of Punjab and reported overall $8.57 \%$ of equid samples positive for $T$. equi by primary PCR. Moreover, high prevalence of $T$. equi through PCR in other parts of world had been reported as $27.7 \%$ by Ebrahimi et al. (2018) from Iran, $66.0 \%$ by Montes Cortesa et al. (2019) from Spain and $50.00 \%$ by Sharon et al. (2020) from Israel.

\section{CONCLUSION}

cELISA is useful as an efficient diagnostic assay to determined $T$. equi and $B$. caballi antibodies from carrier horses. PCR was more useful diagnostic assay for the detection of $T$. equi than blood smear examination. Further research is needed to compare different diagnostic techniques in different regions, to identify the specific piroplasm and to produce geographic distribution maps of equine piroplasms in Gujarat and elsewhere for better understanding the epidemiology of equine piroplasmosis.

\section{REFERENCES}

Bharai, M.J. (2018). Clinical studies on prevalence and therapeutic management of equine piroplasmosis in horses (M.V.Sc. Thesis). Junagadh Agricultural University, Gujarat. India.
Bharai, M.J., Patel, J.S., Parmar, V.L., Patel, U.D. and Fefar, D.T. (2020). Prevalence of equine piroplasmosis in and around Junagadh in horses. Indian Journal of Veterinary Sciences and Biotechnology. 15(3): 49-51.

Bhojani, R.J., Chahar, A., Dewal, V.S., Mandal, K.D., Chauhan, S.L., Pal, Y., Kumar, R. and Kumar, S. (2021). Seroprevalence and risk factor associated with endemicity of Theileria equi infection in horses in Rajasthan State, India. Indian Journal of Animal Research. DOI: 10.18805/IJAR.B-4325.

Dahiya, R., Salar, R.K., Mandal, K.D., Kumar, R., Tripathi, B.N., $\mathrm{Pal}$, Y. and Kumar, S. (2018). Risk factor analysis associated with Theileria equi infected equines in semiarid and subhumid ecological enzootic zones of India. Veterinary Parasitology: Regional Studies and Reports. 12: 17-21.

De Waal, D.T. (2004). Equine piroplasmosis. In: Infectious Diseases of Livestock, [Coetzer, J.A. W. and Tustin, R.C. (Eds.)], $2^{\text {nd }}$ Ed., Oxford University Press, New York. pp. 425-434.

Diallo, T., Singla, L.D., Deepak, S., Paramjit, K. and Bal, M.S. (2018). Conventional and molecular diagnosis of haemo-protozoan infections in cattle and equids from Republic of Guinea and India. Indian Journal of Animal Research. 52(8): 1206-1211.

Ebrahimi, M., Adinehbeigi, K., Hamidinejat, H. and Tabandeh, M.R. (2018). Molecular characterization of Theileria equi infection in horse populations belonging to West Azerbaijan, Iran: insights into the importance of Equine Merozoite Antigen (EMA)- 1 in its diagnosis. Annals of Parasitology. 64(1): 21-27.

Khurana, S.K., Singh, B.K., Yadav, S.C., Gulati, B.R., Malik, P., Kumar, R., Virmani, N., Kumar, S., Barua, S., Vaid, R.K., Manuja, A., Dedar, R. and Singha, H. (2014). Surveillance, monitoring and control of existing and emerging diseases of equines. National Research Centre on Equines (NRCE), Annual Report (2013-2014). Hisar-125 001, India, pp.26.

Montes Cortesa, M.G., Fernandez-Garciab, J.L. and Habela Martinez-Estelleza M.A. (2019). A multinested PCR for detection of the equine piroplasmids Babesia caballi and Theileria equi. Ticks and Tick Borne Diseases. 10(2): 305-313.

OIE (2014). Equine piroplasmosis. In: Manual of Diagnostic Tests and Vaccines for Terrestrial Animals. $6^{\text {th }}$ Edition. Paris, France. pp. 884-891.

Patel, G., Shanker, D., Jaiswal, A.K., Sudan, V. and Verma, S.K. (2013). Prevalence and seasonal variation in ixodid ticks on cattle of Mathura district, Uttar Pradesh. Journal of Parasitic Diseases. 37: 173-176.

Sanjeev, K., Vikrant, S., Daya, S. and Anjali, D. (2020). Babesia (Theileria) equi genotype $A$ among Indian equine population. Veterinary Parasitology: Regional Studies and Reports. 19: 100367. 
Sharon, T., Amir, S., Hadas, L., Yotam, K., Margarita, S. and Yuval, G. (2020). Parasite load and genotype are associated with clinical outcome of piroplasm infected equines in Israel. Parasites and Vectors. 13: 267-270.

Snedecor, G.W. and Cochran, W.G. (1994). Statistical Methods, $8^{\text {th }}$ Ed. Oxford and IBH Publishing Co. Calcutta, India.

Sumbria, D., Singla, L.D., Sharma, A. and Kaur, P. (2016). Detection of Theileria species infecting equine population in Punjabby $18 S$ rRNA PCR. Indian Journal of Animal Research. 50(2): 218-223.
Vidhyalakshmi, T.M. (2015). Studies on epidemiology, hematobiochemistry and seroprevalence of piroplasmosis in horses. M.V.Sc (Vet) Thesis. Anand Agricultural University, Gujarat, India. Vidhyalakshmi, T.M., Sunant, K.R., Bharat, B.B. and Amit, K.K. (2018). Prevalence of Theileria equi among Horses Based on Parasitological and Universal Molecular Technique. International Journal of Current Microbiology and Applied Sciences. 7(10): 318-323. 